\title{
Disintegration per Second
}

National Cancer Institute

\section{Source}

National Cancer Institute. Disintegration per Second. NCI Thesaurus. Code C94885.

A unit of radioactive decay expressed in atoms of radioactive material that decay over a

period of time equal to one second. 